\title{
The Relationship between Glycated Hemoglobin Levels and the Quality of Life among Type 1 Diabetes Mellitus in Children
}

\author{
Susilowati Susilowati*, Karina Sugih Arto, Aridamuriany. D. Lubis \\ Department of Child Health, Faculty of Medicine, Universitas Sumatera Utara, Medan, Indonesia
}

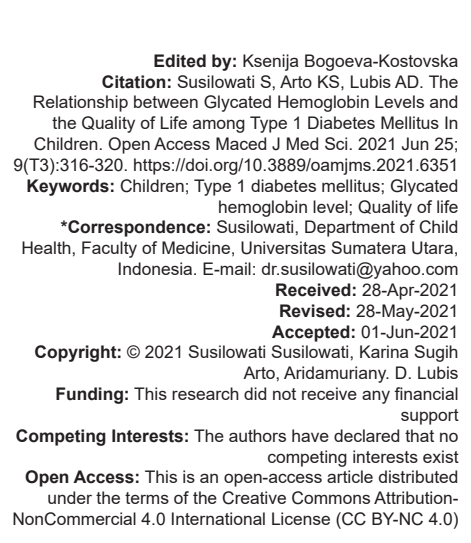

\section{Introduction}

Definition of diabetes mellitus is a systemic disorder resulting from a glucose metabolism disorder characterized by chronic hyperglycemia [1]. Diabetes mellitus type 1 (T1DM) is the most common diabetes disease in children, caused by autoimmune or genetic processes. Autoimmune processes result in damage to pancreatic beta cells resulting in decreased insulin production. These abnormalities in the pancreas are usually permanent [2], [3].

The incidence of DM has continued to increase in the last few years. Data from the Association of Hospitals throughout Indonesia (PERSI) explains that Indonesia is in the fourth rank after the United States, China, and India. The incidence of T1DM in children and adolescents based on data from the Indonesian Pediatrician Association (IDAI) has increased about sevenfold in the last 10 years with the number of T1DM sufferers throughout Indonesia as many as 1220 children in 2018. The prevalence of DM cases based on data from the 2018 Basic Health Research (RISKESDAS) shows an increase to 8.5\% [4], [5].

Uncontrolled glycemic levels can cause death, disability and can indirectly reduce the quality of life due to complications arising such as diabetic ketoacidosis, hypoglycemia, cardiovascular disease, cerebrovascular disease, neuropathy, nephropathy, retinopathy, and foot ulcers. Young age, puberty, and poor metabolic control are the factors that cause complications due to T1DM [6]. The Diabetes Control and Complications Trial (DCCT) states that 1\% difference in glycated hemoglobin $(\mathrm{HbA} 1 \mathrm{C})$ reduces the risk of complications by $25-50 \%$ [7].

$\mathrm{HbA} 1 \mathrm{C}$ is a standard metabolic control parameter and has a strong predictive value for diabetes complications. $\mathrm{HbA} 1 \mathrm{C}$ will increase if there has been a non-enzymatic glycosylation process of hemoglobin. $\mathrm{HbA} 1 \mathrm{C}$ formation is substantially irreversible and its concentration in blood depends on blood glucose concentration and the life span of red blood cells, which averages 120 days [8], [9]. HbA1C $<7 \%$ means good metabolic control; $\mathrm{HbA} 1 \mathrm{C}<7 \%$ was considered poor [10], [11].

Very few studies to assess the psychosocial effects of diabetes were carried out on children. Pediatric quality of life inventory (PedsQL) 4.0 is an instrument for measuring the quality of life in children that meet the standards recommended by $\mathrm{WHO}$ is an instrument to measure the quality of life for healthy children and adolescents and children with acute and 
chronic diseases which include physical, emotional aspects, and psychosocial with validity and reliability standards [12], [13]. Previous studies reported that there was a relationship between $\mathrm{HbA} 1 \mathrm{C}$ and quality of life of children with TIDM where children who achieved the $\mathrm{HbA} 1 \mathrm{C}$ target of $<7.5 \%$ reported higher quality of life; $\mathrm{HbA} 1 \mathrm{C}>7.5$ and $<9.0 \%$ reported significantly lower quality of life; the worst control with $\mathrm{HbA} 1 \mathrm{C}$ $>9.0 \%$ reported significantly lower quality of life than each of the other two HbA1C groups [14].

The aim of this study was to assess the relationship between $\mathrm{HbA} 1 \mathrm{C}$ and the quality of life among type 1 diabetes mellitus in children at Central General Hospital Haji Adam Malik and Universitas Sumatera Utara hospital Medan.

\section{Methods}

\section{Study design}

The design of this study was an observational analytic study with a cross-sectional design in children who experienced T1DM at Central General Hospital Haji Adam Malik and Universitas Sumatera Utara hospital Medan.

\section{Study setting and participant}

The study was conducted from April 2020 to July 2020 at pediatric endocrine clinic Central General Hospital Haji Adam Malik and Universitas Sumatera Utara Hospital Medan. The participants were children who were fulfill the criteria of T1DM.

\section{Instrument}

Pediatric quality of life inventory (PedsQL) 4.0 which is a generic measurement scale consisting of 23 items that are designed according to the health dimensions recommended by WHO and have excellent internal PedsQL reliability, with a Cronbach alpha value of 0.9 for parent/guardian reports and 0.88 for children's self-reports. The items in the generic PedsQL 4.0 consist of 4 major groups - physical functions (8 questions), emotional functions (5 questions), school functions (5 questions), and social functions (5 questions).

This questionnaire consists of several subgroups of reports according to age groups - the reports of children: (1) Younger children (5-7 years); (2) older children (8-12 years); (3) adolescents (13-18 years), and parental reports; (1) toddlers (2-4 years); (2) younger children (5-7 years); (3) older children (8-12 years), and (4) adolescents (13-18 years). Each score received from the participants was transformed into a scale of $0-100(0=100 ; 1=75 ; 2=50 ; 3=25 ; 4=0)$.
The calculation of the total score of 23 items is the average of all the number of items answered divided by the number of items answered. The higher score indicates a better quality of life with a cut point value for the quality of life of a good child 70 (healthy children have a score of about 83 with the lowest score of 70 ), whereas it is said to be affected if they have a score $<70$ (mean value 60 to $<70$ ).

\section{Sample and data collection}

Children aged 5-18 years who are diagnosed with T1DM and have been tested for $\mathrm{HbA} 1 \mathrm{C}$ were included and those with mental retardation were excluded from the study. Once the subject was approached, the questionnaire was explained and guided by the researcher. Informed consent was obtained from their parent and assent from the patients before answering of the questionnaire. Basic data and anthropometric examinations were performed to determine nutritional status. Participants were allowed to opt-out from the study if they did not wish to participate in the study.

\section{Statistical analysis}

All data were entered using SPSS version 20.0 for Macintosh (SPSS Inc). Descriptive statistics were used to describe sociodemographic information. Categorical data were expressed in number and percentage. Numerical data were expressed in mean and standard deviation. Non-normally distribution data were described as median and interquartile range. Knowledge and attitude were expressed as frequency and percentages. Fisher's Exact test used to determine the association between two categorical variables. Pearson and Spearman correlation test analysis was conducted to assess the correlation between $\mathrm{HbA} 1 \mathrm{C}$ levels and the quality of life of children with T1DM. The significance level and the confidence interval used were $p<0.05$ and $95 \%$, respectively.

\section{Ethical approval}

The study was approved by the Research and Ethics Committee, Faculty of Medicine, Universitas Sumatera Utara.

\section{Results}

\section{Sociodemographic data}

This study was attended by 30 participants. A total of 17 people $(56.7 \%)$ were female patients with a mean age of 15.17-year-old. Most of the participants had good nutritional status (76.7\%). Father of participants 
had formal education up to university (66.7\%) and the most occupations being private employees (26.6\%). Maternal education level was mostly up to high school as many as 14 people $(46.7 \%)$, whereas most occupations being housewives (56.6\%). Fifty percent of the family has a monthly household income below the regional minimum wage.

More than half of the participants (56.7\%) did not have a family history of diabetes with a mean length of suffering from diabetes were 2.63 years. All participants were received insulin injections at the age above 5 years with the highest frequency was more than 3 times a day. A total of 13 people $(43.4 \%)$ did not do the regular blood sugar test every day. As many as 20 subjects $(66.7 \%)$ did exercise $<3$ times a week. Sixty percent of the participants had never been hospitalized. Most of the participants (53.3\%) were actively involved in a school activity (Table 1).

The mean level of $\mathrm{HbA} 1 \mathrm{C}$ was $10.35 \%+2.65 \%$, with minimal score was $5.60 \%$ and maximal score was 14.9. The mean score of the quality of life was $87.72+3.59$, minimal score was 77 and maximal score was 95 (Table 2).

Table 1: Sociodemographic characteristics of the study subjects $(n=30)$

\begin{tabular}{|c|c|}
\hline Karakteristik demografi Subyek & $\mathrm{n}=30$ \\
\hline \multicolumn{2}{|l|}{ Gender, n (\%) } \\
\hline Male & $13(43,3)$ \\
\hline Female & $17(56,7)$ \\
\hline Age (SD), year & $15,1(1,64)$ \\
\hline \multicolumn{2}{|l|}{ Nutritional status, n (\%) } \\
\hline Malnutrition & $5(16,7)$ \\
\hline Well nourished & $23(76,7)$ \\
\hline Overweight & $2(6,7)$ \\
\hline \multicolumn{2}{|l|}{ Education level, n (\%) } \\
\hline Junior high school & $12(40,0)$ \\
\hline Senior high school & $18(60,0)$ \\
\hline \multicolumn{2}{|l|}{ Father's education level, n (\%) } \\
\hline Junior high school & $3(10,0)$ \\
\hline Senior high school & $7(23,3)$ \\
\hline University & $20(66,7)$ \\
\hline \multicolumn{2}{|l|}{ Father's employment status n (\%) } \\
\hline Working & $30(100)$ \\
\hline Not working & $0(0)$ \\
\hline \multicolumn{2}{|l|}{ Mother's education level, n (\%) } \\
\hline Junior high school & $5(16,7)$ \\
\hline Senior high school & $14(46,7)$ \\
\hline University & $11(36,6)$ \\
\hline \multicolumn{2}{|l|}{ Mother's employed status, n (\%) } \\
\hline Working & $13(43.3)$ \\
\hline Not working & $17(56,6)$ \\
\hline \multicolumn{2}{|l|}{ Family income, n (\%) } \\
\hline Above UMR & $15(50,0)$ \\
\hline Below UMR & $15(50,0)$ \\
\hline \multicolumn{2}{|l|}{ Family history of DM, n (\%) } \\
\hline Yes & $13(43,3)$ \\
\hline No & $17(56,7)$ \\
\hline Disease onset (SD), year & $2,6(1,30)$ \\
\hline \multicolumn{2}{|l|}{ Frequency of insulin SC, n (\%) } \\
\hline$<3$ times perday & $9(30.0)$ \\
\hline$\geq 3$ times per day & $21(70.0)$ \\
\hline \multicolumn{2}{|l|}{$\begin{array}{l}\text { Frequency of blood sugar } \\
\text { monitoring, } \mathrm{n}(\%)\end{array}$} \\
\hline 1 time per day & $10(33.3)$ \\
\hline$>1$ time per day & $7(23.3)$ \\
\hline Not everyday & $13(43.3)$ \\
\hline \multicolumn{2}{|l|}{ Frequency of exercise, $n(\%)$} \\
\hline$<3$ times per week & $20(66.7)$ \\
\hline$\geq 3$ times per week & $8(26.7)$ \\
\hline Everyday & $2(6.7)$ \\
\hline \multicolumn{2}{|l|}{ School activity, n (\%) } \\
\hline Never & $5(16.7)$ \\
\hline Sometimes & $9(30)$ \\
\hline Active & $16(53.3)$ \\
\hline
\end{tabular}

Table 2: The mean of HbA1C level and quality of life score from 30 respondent

\begin{tabular}{llll}
\hline Variable & minimal score & Maximal score & Mean \pm SD \\
\hline HbA1C & 5.60 & 14.9 & $10.35 \pm 2.68$ \\
Quality of Life & 77 & 95 & $87.72 \pm 3.59$ \\
\hline HbA1C: Glycated hemoglobin. & &
\end{tabular}

\section{The relationship between $\mathrm{HbA1C}$ and The} quality of life of children with T1DM

In this study, the bivariate statistical analysis only could be carried out between $\mathrm{HbA1C}$ and emotional function. Since other components function, such as physical, social, and school functions as well as the total quality of life was not affected (Table 3 ). Table 3: Hubungan Antara HbA1C Terhadap Kualitas Hidup Fungsi Emosi Anak dengan DMT I

\begin{tabular}{llll}
\hline HbA1C & \multicolumn{2}{l}{ Fungsi Emosi } & $\mathrm{p}$ \\
\cline { 2 - 3 } & Terganggu & Tidak Terganggu & \\
\hline$>7 \%$ & $4(16.7)$ & $20(83.3)$ & $0.571^{*}$ \\
$\leq 7 \%$ & $2(33.3)$ & $4(66.7)$ &
\end{tabular}

Based on the correlation analysis, it can be concluded that there was no significant correlation between $\mathrm{HbA} 1 \mathrm{C}$ levels and all components of the quality of life function and the total quality of life score $(p>0.05)$ (Table 4).

Table 4: Correlation of HbA1C and quality of life of children with T1DM

\begin{tabular}{lll}
\hline HbA1C & $\mathrm{p}$ & $\mathrm{r}$ \\
\hline Physical functions & $0.944^{\mathrm{a}}$ & 0.013 \\
Emotional function & $0.138^{\mathrm{b}}$ & 0.277 \\
Social functions & $0.225^{\mathrm{a}}$ & 0.228 \\
School functions & $0.899^{\mathrm{a}}$ & -0.024 \\
Total quality of life score & $0.159^{\mathrm{a}}$ & 0.264 \\
\hline${ }^{\mathrm{a}}$ Spearman, ${ }^{\mathrm{b}}$ Pearson. HbA1C: Glycated hemoglobin, T1DM: Type 1 diabetes mellitus. &
\end{tabular}

\section{Discussion}

\section{The characteristic of research subjects}

The incidence of DM has continued to increase in recent years. The incidence of T1DM in children and adolescents based on data from the IDAI has increased about seven times in the last 10 years with the number of diabetes mellitus cases throughout Indonesia as many as 1220 children in 2018 [4].

A total of 30 pediatric patients who came for treatment at the Pediatric Endocrinology Clinic at the Haji Adam Malik Central General Hospital and the Universitas Sumatera Utara Hospital Medan were involved with the mean age 15.17-year-old and predominantly were female with an average length of suffering from diabetes were $2.6 \pm 1.30$ years. Similar with the previous study by Nansel et al. was found that the mean age of the children in the study was 11.5 years [15]. Ozyazicioglu et al. showed that the mean age of children with diabetes was 14.96-yearold [16]. Children with T1DM in this study mostly had good nutrition status and only 5 children had 
malnutrition. Other study also found that the majority nutritional status of children and adolescents were involved in the study was good [17].

The rate of $\mathrm{HbA} 1 \mathrm{C}$ formation is directly proportional to the concentration of glucose in the blood. $\mathrm{HbA} 1 \mathrm{C}$ is the integrated value for glucose during the previous 8-12 weeks. Based on the DCCT results, a $1 \% \mathrm{HbA} 1 \mathrm{C}$ difference reduces the risk of complications by $25-50 \%$ [7]. HbA1C has a strong predictive value for diabetes complications [8], [9]. Measurement of $\mathrm{HbA} 1 \mathrm{C}$ levels should be performed routinely in all patients with diabetes as an initial assessment and as part of ongoing care. Measurements of the indicator of glycemic control are $\mathrm{HbA} 1 \mathrm{C}$. Majority of the mean level of $\mathrm{HbA} 1 \mathrm{C}$ from our study was more than $7 \%$. In line with other studies conducted in Turkey, Egyptian as well as research in Khartoum also reported similar finding that was reflected that the most of the children that involved in the studies had poor glycemic control [18], [19], [20]. Low parental education levels, low economic income, and limitation of the health care service were postulated as the cause of poor glycemic control in children with T1DM [20].

\section{The relationship between $\mathrm{HbA1C}$ and The quality of life of children with T1DM}

This study was shown that from physical, emotional, social, and school function only emotional function was affected in six children. However, when the Spearman correlation test was conducted, none of the functions and the quality of life were statistically had a significant correlation with $\mathrm{HbA} 1 \mathrm{C}$ level $(r=0.264$, $p>0.05$ ). This is in line with the research conducted by Ali et al. (Egypt) which states that the PedsQL domain shows no significant difference between children with good controls and poor controls T1DM ( $p>0.05$ for all domains) [21]. Consistent with previous research, Emmanouilidou (Greece) conducted a study on 89 children with T2DM also explained that there was no difference between $\mathrm{HbA} 1 \mathrm{C}$ and the quality of life of children with T1DM [22]. Although there is no physical activity limitation for children with T1DM, emotional problems such as anger and psychosocial problems can arise [22]. On the other hand, it is known that once children and adolescents were diagnosed, they find it difficult to get used with their conditions.

Contrary with Linear multivariate studies conducted by TEENs in several countries on children aged 8-25 years with T1DM indicated that there was a linear relationship between $\mathrm{HbA} 1 \mathrm{C}$ and quality of life [14]. Low parental education levels, low economic income, and thus incapacity providing optimal health care may be the cause of poor glycemic control of children with T1DM [21]. In keeping with research by Rasoul showed that there was a significant relationship between the total PedsQL score and the mean HbA1C level, where all age groups with good metabolic control had higher total emotional and social scores [17]

In a study conducted by Ozyazicioglu et al., it was stated that adolescents have an increased risk of psychosocial problems. The relationship between $\mathrm{HbA} 1 \mathrm{C}$ levels in adolescents of 13-18-year group and the total PedsQL score had a significant correlation to emotional function, social function, school function, and total PedsQI. The presence of diabetes makes a person feel different and isolated, reduced efforts to be independent, effect on family control, and causes a decline in a person's metabolic control. Adolescents as a result of the conflict in the family [16]. The initial manifestations of complication T1DM are due to ignorance of early symptoms of the disease, infection, lack of glucose control, psychological problems, and medical costs that are not covered by insurance or the government [23].

\section{Conclusions}

This study was shown that the majority of the children had poor glycemic control. However, only few children had emotional function affected. Domain physical, social, and school function were not affected. The lack of association between $\mathrm{HbA} 1 \mathrm{C}$ level and the quality of life may be related to the number of sample since the study was conducted during pandemic COVID-19, this condition was affect the number of patients who attended to our clinic. Our study also did not used the generic and diabetes-specific PedsQL modules which more specific for children with diabetes, since the questionnaire still not available in Indonesian. Further research with a larger sample size and specific PedsQL modules for diabetes children is indicated.

\section{References}

1. Rustama DS, Yati NP, Adriana N, Pulungan AP. Diabetes Mellitus tipe I. In: Batubara JR, Tridjaja B, Pulungan AB, editors. Buku Ajar Endokrinologi Anak. Jakarta: Ikatan Dokter Anak Indonesia; 2017. p. 146-230. https://doi.org/10.14238/sp13.5.2012.367-72

2. Alemzadeh $\mathrm{R}$, Ali $\mathrm{O}$. Diabetes mellitus. In: Kliegman RM, editors. Nelson Textbook of Pediatrics. $19^{\text {th }}$ ed. Amsterdam, Netherlands: Elsevier-Saunders; 2011. p. 1968-93

3. Perkumpulan Endokrinologi Indonesia. Patofisiologi Diabetes Melitus. Jakarta: PB. PERKENI; 2006.

4. Pulungan AB, Annisa D, Imada S. Type-1 Diabetes Mellitus in Children: Situation in Indonesia and Management. Sari Pediatr. 2019;20(6):392-400. https://doi.org/10.14238/ sp20.6.2019.392-400

5. Badan Penelitian dan Pengembangan Kesehatan Kementerian Kesehatan RI. Riset Kesehatan Dasar. Bakti Husada; 2018. p. 66-75. https://doi.org/10.22435/jpppk.v1i1.430

6. UKK Endokrinologi Ikatan Dokter Anak Indonesia. Diagnosis 
dan tata Laksana Diabetes Mellitus Tipe- 1 Pada anak dan Remaja. Jakarta: Ikatan Dokter Anak Indonesia; 2017. https:// doi.org/10.36053/mesencephalon.v6i1.189

7. Diabetes Control and Complications Trial Research Group. The effect of intensive treatment of diabetes on the development and progression of long-term complications in insulin-dependent diabetes mellitus. N Engl J Med. 1993;329(14):977-86. https:// doi.org/10.1056/nejm199309303291401

PMid:8366922

8. Shapiro R, McManus MJ, Zalut C, Bunn HF. Sites of nonenzymatic glycosylation of human hemoglobin A. J Biol Chem. 1980;255(7):3120-7. https://doi.org/10.1016/ s0021-9258(19)85860-

PMid:7358733

9. Welsh KJ, Kirkman MS, Sacks DB. Role of glycated proteins in the diagnosis and management of diabetes: Research gaps and future directions. Diabetes Care. 2016;39(8):1299-306. https:// doi.org/10.2337/dc15-2727

PMid:27457632

10. American Diabetes Association. 6. Glycemic targets: Standards of medical care in diabetes 2018. Diabetes Care. 2018;41(Supp 11):55-64. https://doi.org/10.2337/dc19-s006 PMid:29222377

11. Miller KM, Beck RW, Bergenstal RM, Goland RS, Haller MJ, McGill JB, et al. Evidence of a strong association between frequency of self-monitoring of blood glucose and hemoglobin A1c levels in T1D Exchange clinic registry participants. Diabetes Care. 2013;36(7):2009-14. https://doi.org/10.2337/dc12-1770 PMid:23378621

12. Varni JW, Burwinkle TM, Seid M. The PedsQL patients report outcome: Realibility and validity of the PedsQL measurement model in 25.000 children. Rand Health. 2005;5(6):705-10. https://doi.org/10.1586/14737167.5.6.705 PMid:19807613

13. Gheissari A, Farajzadegan Z, Heidary M, Salehi F, Masaeli A, Varni JW, et al. Validation of persian version of PedsQL $L^{\mathrm{TM}} 4.0^{\mathrm{TM}}$ generic core scales in toddlers and children. Int J Prev Med. 2012;3:341-50

14. Anderson BJ, Laffel LM, Domenger C, Danne T, Phillip M, Mazza C, et al. Factors associated with diabetes-specific health-related quality of life in youth with Type 1 diabetes: The global TEENs study. Diabetes Care. 2017;40(8):1002-9. https:// doi.org/10.2337/dc16-1990 PMid:28546221

15. Nansel TR, Weisberg-Benchell J, Wysocki T, Laffel L, Anderson B. Quality of life in children with Type 1 diabetes: A comparison of general and diabetes-specific measures, and support for a unitary diabetes quality of life construct. Diabet Med. 2008;25(11):1316-23. https://doi. org/10.1111/j.1464-5491.2008.02574.x

PMid:19046222

16. Ozyazicioglu N, Avdal EU, Saglam H. A determination of the quality of life of children and adolescents with Type 1 diabetes and their parents. Int J Nurs Sci. 2017;4(2):94-8.

PMid:31406726

17. Abdul-Rasoul M, AlOtaibi F, Rahme Z, Alshawaf F. Quality of life children and adolescents with Type 1diabetes in Kuwait. Med Princ Pract. 2013;22(4):379-84. https://doi. org/10.1159/000347052 PMid:23428425

18. Monir ZN, El Samahy MH, Eid EM, Khalifa AG, abd-El Maksoud SE, Abbas MA, et al. Healthrelated quality of life in a group of Egyptian children and adolescents with Type 1 diabetes: Relationship to microvascular complications. Bull Natl Res Centre. 2019;43(142):1-14. https:// doi.org/10.1186/s42269-019-0180-0

19. Taha Z, Eltoum Z, Washi S. Predictors of glucose control in children and adolescents with Type 1 diabetes: Results of a crosssectional study in Khartoum, Sudan. Open Access Maced J Med Sci. 2018;6(11):2035-9. https://doi.org/10.3889/oamjms.2018.423 PMid:30559856

20. Hapunda G, Abubakar A, Van de Vijver F, Pouwer F. Living with Type 1 diabetes is challenging for Zambian adolescents: Qualitative data on stress, coping with stress and quality of care and life. BMC Endocr Disord. 2015;15(1):20. https://doi. org/10.1186/s12902-015-0013-6 PMid:25928592

21. Ali BA, Abdel-Hakm AM, Abdel-Hameed MA, Tawfik NK. Quality of life in children with Type I diabetes mellitus (T1D) in Minia governorate: Relationship with mood and family attitudes. J Diabetes Metab. 2017;8(2):1-5. https://doi. org/10.4172/2155-6156.1000725

22. Emmanouilidou E, Galli-Tsinopoulou A, Karavatos A, Nousia-Arvanitakis S. Quality of life of children and adolescents with diabetes of Northern Greek origin. Hippokratia 2008;12(3):168-75

PMid: 18923667

23. Lukacs A, Varga B, Kiss-Toth E, Soos A, Barkai L. Factors influencing the diabetes-specific health-related quality of life in children and adolescents with Type 1 diabetes mellitus. J Child Health Care. 2014;18(3):253-60. https://doi. org/10.1177/1367493513486964

PMid:23749254 